\title{
Erratum to: Review of Inna Semetsky, The Edusemiotics of Images: Essays on the Art Science of Tarot
}

Ronald Bogue

Published online: 2 September 2014

(C) Springer Science+Business Media Dordrecht 2014

Erratum to: Stud Philos Educ (2014) 33:563-569

DOI 10.1007/s11217-014-9427-2

The original version of the article has been inadvertently published with the incorrect title. The correct title should read as.

"Review of Inna Semetsky, The Edusemiotics of Images: Essays on the Art Science of Tarot"

The online version of the original article can be found under doi:10.1007/s11217-014-9427-2.

R. Bogue $(\bowtie)$

University of Georgia, 214 Joseph E Brown Hall, Athens, GA 30602, USA

e-mail: rbogue@uga.edu 